\title{
M icro-histological analysis of faeces of Chukar partridge Alectoris chukar gray in Garhwal Himalaya, Uttarakhand, India
}

\author{
M anish K ukreti*, Surman A rya and Suneel K umar Singh ${ }^{1}$
}

Department of Zoology, Government Post Graduate College, Gopeshwar, Chamoli, (Uttarakhand), INDIA 'Department of Biotechnology, Modern Institute of Technology, Dhalwala, Rishikesh - 249 201, (Uttarakhand), INDIA

*Corresponding author: Email: manishkukreti15@gmail.com

Received:J uly 21, 2013; Revised received: August 8, 2013; Accepted: 0 ctober 25, 2013

\begin{abstract}
In vivo studies on the feeding of Chukar partridge (Alectoris chukar Gray) in Garhwal Himalaya, Uttarakhand and micro-histological analysis of 104 samples of its faeces were investigated during January 2011 to December 2012, to get information on vegetative and non-vegetative diet and feeding behaviour. Plant matter constituted a major portion of the faecal content $(87.73 \pm 4.31 \mu \mathrm{g})$ and represented by 14 families. Non- vegetative matter could be recorded as $9.36 \pm 1.46 \mu \mathrm{g}$ of dry weight which represented by 8 orders of the arthropods. Fine organic matter + grits constitute was found to be $2.84 \% \pm 1.17 \mu \mathrm{g}$ in faecal content. Saxifragaceae, Graminaceae, Rosaceae, Poaceae and Fabaceae were found the best plant families for Chukar diet while arthropod insects order like Diptera, Dissotera, Hymenoptera and Araneae remained favorite feeds. Flowers and fruits of Rhus parviflora, leaves of Rumax, roots/ tuber of Vigna and fruits of R ubus were found important diet of Chukar partridge along with Triticum in Rabi crop and Oryza in Kharif. Flies, grasshoppers, spiders were observed the main insects diet of Chukar partridge.
\end{abstract}

Keywords: Arthropods, Chukar partridge, Faecal analysis, Plants

\section{INTRODUCTION}

Chukar partridge (or Chakor) Alectoris chukar Gray is distributed in many parts of the world, like America, New Zealand, Canada, Pakistan, India and Nepal. In Indian subcontinent it occurs throughout the western Himalayas between 1200 to $5000 \mathrm{~m}$ elevation east to central Nepal and also in the salt range of Punjab (Hume and Marshall, 1879, Ali and Ripley, 1983). It inhabits open, stony, semiarid and steep slopes covered with scattered trees, dense perennial shrubs and grass near cultivated fields. In Garhwal Himalaya, Chukar is a pest bird because coveys of this bird damage seeds and germinating shoot in the crop fields. Faecal analysis is an ideal method to determine food and feeding habits of the wild animals (Holechek, 1982 and Hinnant and Kothmann, 1988). A good correlation between diet and undigested faecal contents is observed in many game birds as well as wild animals (Marti, 1982; Alipayo et al., 1992; Moreby, 1993; Rumble and Anderson, 1993; Katona and Altbacker, 2002; Walter and Reese, 2003; Balestrieri et al., 2011; Ndawula et al., 2011; Bergstrom, 2013). Literature on the diet of Chukar partridge in Himalayan regions revealed lacuna in the field. It is said that these feeds on roots, tuber, seeds and grains in addition to insects (Galbreath and Moreland, 1953; Sandfort, 1954; Christensen, 1996). Present paper deals with the diet identification and droppings of Chukar, based on microhistological analysis. ISSN : 0974-9411 (Print), 2231-5209 (Online) All Rights Reserved ๑ Applied and Natural Science Foundation www.ansfoundation.org

\section{MATERIALS AND METHODS}

Study site chosen was Ranshi $\left(30^{\circ} 15^{\prime} \mathrm{N}\right.$ and $78^{\circ} 30^{\prime} \mathrm{E}$; $1950 \mathrm{~m}$ altitude; located in district Pauri Garhwal, Uttarakhand) because of the mixed temperate forest, where different types of trees, herbs, shrubs, climbers occur. Basically, Pinus roxburghii, Cupressus, Cedrus, Rhododendron, Berberis, Rubus, Rhus parviflora, Rosa brunonaii, Stephania, rocky areas and crop fields surrounded adjacent villages. Many animals, reptiles, birds and variety of non-chordates are found in Ranshi forested areas.

Faecal pellets of Chukar were collected from the roosting sites, especially from rocky out cliffs and under bushes, during January 2011 to December 2012. All the collected pellets were then air dried in shade, at room temperature in laboratory. Month-wise (season-wise) collected samples were stored in sealed plastic bags, kept in oven at $60^{\circ} \mathrm{C}$ for $30 \mathrm{~min}$. to remove moisture and then weighed to calculate mean group weight. The faecal samples were soaked in water for 3-5 days and later on sieved through a $212 \mu \mathrm{m}$ mesh for analysis (Moreby, 1993). The material retained on sieve after gentle washing was stored in $70 \%$ alcohol. Small amount of these retained samples was evenly distributed on a $10 \mathrm{~cm}$ petri dish scored with $1 \mathrm{~cm}^{2}$ grid and examined (under a polarized light microscope at 100X. Microphotographs of different fragments were observed at 20X, 50X and 100X magnifications and were 
identified with the help of text (Sharp, 1968; Warburton, 1968), photographic acids (Satakopan, 1972; Ralph et al., 1985; Moreby, 1993) and reference slides prepared from the herbarium and insects samples collected from study site.

\section{RESULTS}

A total of 104 sample sizes were collected during different season from January 2011 to December 2012. Maximum sample size was collected during breeding season while in winter season only 20 samples could be collected. The micro-histological examination of the droppings results indicated that the diet of Chukar partridge comprises both vegetative (plants + grains) and non-vegetative (animal matter) along with grits. Vegetative part (plants + grains) was recorded as a major portion of the faecal contents $(87.73 \pm 4.31 \mu \mathrm{g}$ of mean dry weight; ranging from $86.73 \pm 4.45 \%$ during spring to $88.60 \pm 3.66 \%$ during monsoon and post-monsoon season (Table 1). On the other hand, non-vegetative contents in faecal were found $9.36 \pm 1.46 \mu \mathrm{g}$ which was nearly 10 time lesser than the vegetative part. In the faecal contents fragments of leaves, seeds, fruits, roots, fibers and grasses were identified which covers 14 plants families (viz., Anacardiaceae, Asteraceae, Berberidaceae, Cruciferae, Cyperaceae, Fabaceae, Graminaceae, Malvaceae, Menispermaceae, Plumbaginaceae, Poaceae, Rosaceae, Saxifragaceae and Urticaceae) (Table 2). Present data indicated that the favorite plant died of Chukar was Saxifragaceae family in which the frequency was noted as $60.58 \pm 8.60 \mu \mathrm{g}$ followed by Graminaceae $(57.41 \pm 12.06 \mu \mathrm{g})$ and Rosaceae $(52.75 \pm 10.28 \mu \mathrm{g})$. Malvaceae family $(12.83 \pm 2.53 \mu \mathrm{g})$ was found least favorite diet of Chukar (Table 2). Roots/Rhizomes of Bergenia, Chloris, Brachiaria, fruits of Rosa, Rubus, seeds of Oryza and roots of Vigna and Cajanus were recorded as main diet of Chukar partridge. Chukar feeds on leaves and flower of Rumax, flowers and fruits of Berberis, rubus and Rosa during summer months. While flowers and fruits of Rhus parviflora, leaves of Incourtosia, Rumax, fruit of Rosa brunonaii and roots/ tubers of Vigna, Cajanus were consumed by Chukar during monsoon and winter seasons. Likewise, Rhus, Rubus, Berberis, Rosa and Rumax were also recorded as important dietary elements of Chukar partridge.

In case of non-vegetative matter, different body parts of arthropods representing 8 orders viz., Araneae, Diptera, Heteroptera, Dissotera, Hymenoptera, Isoptera, Lepidoptera and Zoroptera were identified during present studies. In the faeces of Chukar partridge, maximum traces of Diptera $(42.66 \pm 7.36 \mu \mathrm{g})$ were noted. It was followed by Dissotera $(30.16 \pm 3.75 \mu \mathrm{g})$, Hymenoptera $(24.08 \pm 4.20 \mu \mathrm{g})$ and Araneae $(23.08 \pm 2.07 \mu \mathrm{g})$ respectively (Table 3 ). The flies (Diptera), ant (Hymenoptera), butterflies (Lepidoptera), termite (Isoptera), spiders (Araneae) and Spilostethud pondurs (Heteroptera) were recorded during spring and breeding (February to July). The traces of butterflies, flies and termites were found in the faeces of Chukar partridge throughout the year. Overall fine organic matter with grits remained $2.84 \pm 1.17 \mu \mathrm{g}$.

\section{DISCUSSION}

Different workers have tried to determine the diet of Galliformes in a non-invasive way through the analysis of faeces (Eastman and Jenkins, 1970; Holechek, 1982; Marti, 1982; Hinnant and Kothmann, 1988; Rumble and Anderson, 1993 and Walter and Reese, 2003). Some other workers examined the faeces of mammals to identify the contents in it (Katona and Altbacker, 2002; Balestrieri et al., 2011; Ndawula et al., 2011; Bergstron, 2013). Present report is the first hand study on identifying the feeding habits through micro-histological analysis of faecal matter of Chukar partridge in Uttarakhand areas. Analysis of faecal indicated that Chukar is not exclusively vegetarian bird as reported earlier by Galbreath and Moreland (1953), but found, both vegetative (plants + grains) and nonvegetative diet depending on seasonal availability and abundance. During winter season when heavy snowfall covered the entire field in high altitude, some animals/ birds showed altitudinal migration for feeding and Chukar partridge was also found to do so. Hungarian partridge (Westerskov, 1966) and Grey partridge (Kobriger, 1977)

Table 1. Seasonal and annual mean percent of major components (plants + grains, arthropods and fine organic matter + grits) of faecal contents with corresponding sample size and faecal weight (g) of Chukar partridge at the Site Ranshi, Pauri Garhwal (Uttarakhand) during 2011-2012

\begin{tabular}{|c|c|c|c|c|c|}
\hline \multirow[t]{2}{*}{ Par ameters } & \multirow[t]{2}{*}{ Sample } & \multicolumn{3}{|c|}{ M ean dry weight \pm S.E. $(\mu \mathrm{g})$} & \multirow{2}{*}{$\begin{array}{c}\text { Fine or ganic } \\
\text { matter + grits } \\
(\mu \mathrm{g})\end{array}$} \\
\hline & & Faecal $(\mathrm{g})$ & $\begin{array}{c}\text { Plants + grains } \\
(\mu \mathrm{g})\end{array}$ & Arthropods & \\
\hline W inter (November - January ) & 20 & $1.04 \pm 0.04$ & $88.56 \pm 4.36$ & $7.77 \pm 1.37$ & $3.67 \pm 1.20$ \\
\hline Spring (February - April) & 30 & $1.26 \pm 0.06$ & $86.73 \pm 4.45$ & $11.38 \pm 1.56$ & $1.67 \pm 0.78$ \\
\hline Br eeding (May - July) & 29 & $1.14 \pm 0.04$ & $87.03 \pm 4.78$ & $10.61 \pm 1.35$ & $2.36 \pm 1.57$ \\
\hline $\begin{array}{l}\text { Monsoon and post monsoon } \\
\text { (August - October) }\end{array}$ & 25 & $1.19 \pm 0.08$ & $88.60 \pm 3.66$ & $7.70 \pm 1.25$ & $3.69 \pm 1.14$ \\
\hline Annual & 104 & $1.15 \pm 0.05$ & $87.73 \pm 4.31$ & $9.36 \pm 1.46$ & $2.84 \pm 1.17$ \\
\hline
\end{tabular}


Table 2. Annual mean and frequency percent of major components (plants + grains) encountered as faecal contents of chukar partridge during January 2011 to December 2012 at intensive study site Ranshi, Pauri Garhwal, Uttarakhand.

\begin{tabular}{|c|c|c|c|c|c|}
\hline S. No. & Family & Species & Parts & $\begin{array}{c}\text { M ean dry weight } \\
\pm S E(\mu \mathrm{g})\end{array}$ & $\begin{array}{c}\text { Frequency } \\
(\%)\end{array}$ \\
\hline 1 & Anacardiaceae & Rhus purviflora & Flower / Fruits & $2.90 \pm 0.43$ & $24.16 \pm 7.03$ \\
\hline 2 & Asteraceae & Achillea & Roots & $5.50 \pm 0.76$ & $45.83 \pm 13.08$ \\
\hline 3 & Berberidaceae & Berberis & Flower / Fruits & $5.16 \pm 0.67$ & $43.00 \pm 12.77$ \\
\hline 4 & Cruciferae & B rassica & Leaves / Seeds & $6.02 \pm 0.13$ & $50.16 \pm 3.02$ \\
\hline 5 & Cyperaceae & Incourtosia & Leaves & $5.61 \pm 1.55$ & $44.25 \pm 7.02$ \\
\hline 6 & Fabaceae & Vigna Cajanus & Roots / Tubers & $6.16 \pm 0.78$ & $51.33 \pm 9.37$ \\
\hline 7 & Graminaceae & Chloris Brachiaria & Roots & $6.89 \pm 0.72$ & $57.41 \pm 12.06$ \\
\hline 8 & Malvaceae & Hibiscus & Flower / Roots & $1.54 \pm 0.19$ & $12.83 \pm 2.53$ \\
\hline 9 & Menispermaceae & Tinospora & Flowers/Roots & $3.23 \pm 0.51$ & $26.91 \pm 4.78$ \\
\hline 10 & Plumbaginaceae & Rumax & Leaves / Flower & $5.56 \pm 0.95$ & $46.33 \pm 7.30$ \\
\hline 11 & Poaceae & O ryza & Seeds & $6.20 \pm 0.65$ & $51.66 \pm 10.03$ \\
\hline 12 & Rosaceae & Rosa brunonaii Rubus & Fruits & $6.33 \pm 0.78$ & $52.75 \pm 10.28$ \\
\hline 13 & Saxifragaceae & Berginia & Roots / Rhizome & $7.27 \pm 0.71$ & $60.58 \pm 8.60$ \\
\hline 14 & Urticaceae & Urtica & Leaves & $2.11 \pm 0.26$ & $17.58 \pm 5.07$ \\
\hline
\end{tabular}

Table 3. Annual mean and frequency percent of major components arthropods and fine organic matter + grits) encountered as faecal contents of chukar partridge during January 2011 to December 2012 at intensive study site Ranshi, Pauri Garhwal (Uttarakhand).

\begin{tabular}{llccc}
\hline S. No. & Arthropods/Order & Species & $\begin{array}{c}\text { M ean dry weight } \pm \\
\text { SE }(\mu \mathrm{g})\end{array}$ & Frequency (\%) \\
\hline 1 & Araneae & Spiders & $2.77 \pm 0.44$ & $23.08 \pm 2.07$ \\
2 & Diptera & Flies & $5.12 \pm 0.73$ & $42.66 \pm 7.36$ \\
3 & Dissotera & Grasshoppers & $3.62 \pm 0.38$ & $30.16 \pm 3.75$ \\
4 & Heteroptera & Solder bug & $2.42 \pm 0.61$ & $20.16 \pm 2.06$ \\
5 & Hymenoptera & Ant & $2.89 \pm 0.59$ & $24.08 \pm 4.20$ \\
6 & Isoptera & Termite & $2.66 \pm 0.55$ & $20.50 \pm 2.27$ \\
7 & Lepidoptera & Butterfly & $2.75 \pm 0.73$ & $22.25 \pm 3.07$ \\
8 & Zoroptera & Zorotypus & $2.71 \pm 0.70$ & $22.58 \pm 3.83$ \\
9 & Unidentified & - & $1.73 \pm 1.20$ & $14.41 \pm 0.39$ \\
10 & Fine Organic Matter + Grits & - & $4.85 \pm 1.17$ & $40.41 \pm 7.67$ \\
\hline
\end{tabular}

were noted to be dependent on human habitations and agricultural fields during winter season. In crop fields, bird feed on the waste grains of Oryza (Kharif crop) and freshly sown Triticum (Rabi crop).

All the Galliformes have stout, strong and powerful beak by which it digs out underground vegetative parts, some time more than one and half feet below, as seen in cheer pheasant (Bisht and Phurilatpam, 2004). In addition to vegetative food, the arthropods were found as impotent diet of Chukar partridge during entire season. It may be due to rich protein occurs in arthropodan insects. It appears that Chukar partridge is very selective to aerials flies and grasshoppers in spite of all categories of insects available in the habitat. Ridley and Islam (1987) and Birdlife International (2001) also reported grasshoppers as important food of cheer pheasant. During spring and breeding seasons, high consumption of arthropods added in the diet of male and female Chukar is due to the requirement of energy rich protein food. High consumption of insects in breeding period has also been reported in other game birds like Grey partridge, Perdix perdix (Middleton and Chitty, 1937).

Fine organic matter and stone grits also contribute up to $2.84 \pm 1.17$ percent annually in the faecal matter. Grits has been reported as important content in digestion and might influence the changes in seasonal/ mean-monthly percent. During monsoon $(3.69 \pm 1.14)$ and winter $(3.67 \pm 1.20)$, the higher mean percent of grits might be the result of relatively large amount of vegetative diet taken by Chukar. Breaking down of hard and coarse material of insects/plant parts, Chukar includes grits in their diet. Gionfriddo and Best (1996) also noted large amounts of grits in the crop of birds, having hard and coarse materials. Thus, the present report furnishes first hand information 
on the feeding habits of wild Chukar partridge through the faecal examination. Microhistological analysis of faecal matter will be useful to know the feeding habit of wild birds without any harm to them.

\section{ACKNOWLEDGEMENTS}

Authors are thankful to Principal, Govt. P.G. College, Gopeshwar (Chamoli Garhwal) for lab facility; to forester, Pauri Garhwal range for permitting for collection of faecal matter and to Director, Forest Research Institute, Dehradun for identification of plant species.

\section{REFERENCES}

Ali, S. and Ripley, S.D. (1983). Handbook of birds of India and Pakistan. Vol. II. $2^{\text {nd }}$ edition. Oxford University Press. Bombay.

Alipayo, D., Valdez, R., Holechek, J.L. and Cardenas, M. (1992). Evaluation of microhistological analysis for determining ruminant diet botanical composition. J ournal of Range M anagement, 45(2): 148-152.

Balestrieri, A., Remonti, L. and Prigioni, C. (2011). Assessing carnivore diet by faecal samples and stomach contents: a case study with alpine red foxes. Central E uropean J ournal of Biology, 6(2): 283-292.

Bergstrom, B.J. (2013). Would East African savanna rodents inhibit woody encroachment? Evidence from stable isotopes and microhistological analysis of feces. J ournal of M ammalogy, 94(2): 436-447.

Birdlife International (2001). Threatened Birds of Asia: The Birdlife International Red Data Book. Birdlife International Cambridge, U.K. (see http://www.rdb.or.id).

Bisht, M.S. and Phurilatpam, S. (2004). Distribution, group size and habitat preference of Cheer pheasant $C$ atreus wallichi i in Garhwal Himalaya. Bulletin of Environmental Sciences, XXII (2): 132-136.

Christensen, G.C. (1996). Chukar: Alectoris chukar. The Birds of North America, Philadelphia: The Academy of Natural Sciences of Philadelphia. Ed. Poole, F.G. pp. 1-20.

Eastman, D.S. and Jenkins, D. (1970). Comparative food habits of red grouse in northeast Scotland, using fecal analysis. J ournal of Wildlife M anagement, 34: 612-620.

Galbreath, D.S. and Moreland, R. (1953). The Chukar partridge in Washington. Biology Bulletin 11. Washington Department of Game, Olympia, Washington, USA.

Gionfriddo, J.P. and Best, L.B. (1996). Grit color selection by house sparrows and northern bobwhites. J ournal of Wildlife M anagement, 60: 836-842.

Hinnant, R.T. and Kothmann, M.M. (1988). Collecting, Drying, and Preserving Feces for Chemical and Microhistological Analysis. J ournal of Range M anagement, 41(2): 168-171.

Holechek, J.L. (1982). Sample preparation techniques for microhistological analysis. J ournal of Range M anagement, 35(2): 267-268
Hume, A.O. and Marshall, C.H.T. (1879). The Game birds of India, Pakistan, Bangladesh, Burma, and Sri Lanka, Calcutta, 1: $169-176$.

Katona, K. and Altbacker, V. (2002). Diet estimation by faeces analysis: sampling optimisation for the European hare. Folia Zoologica, 51(1): 11-15.

Kobriger, G.D. (1977). Foods of Hungarian partridge in North Dakota. In: Proceeding of Perdix I. Hungarian partridge workshop (ed. G.D. Kobriger, 66-68). North Dakota Chapter of Wildlife Society.

Marti, C. (1982). Accuracy of faecal analysis for identifying foods of black grouse. J ournal of Wil dl ife M anagement, 46(3): 773-777.

Middleton, A.O. and Chitty, H. (1937). The food of adult partridges, (Perdix perdix and Alectoris rufa) in Great Britain. J ournal of Animal E cology, 6: 322-336.

Moreby, S.J. (1993). Faecal analysis as a method for determining the invertebrate diet of Galliformes and its use in helping to assess food availability. In D. Jenkins (Ed.). Pheasants in Asia 1992. World Pheasant Association, 6772 .

Ndawula, J., Tweheyo, M., Tumusiime, D.M. and Eilu, G. (2011). Understanding sitatunga (Tragelaphus spekii) habitats through diet analysis in Rushebeya-Kanyabaha wetland, Uganda. African J ournal of E cology, 49: 481-489.

Ralph, C.P., Nagata, S.E. and Ralph, C.J. (1985). Analysis of droppings to describe diets of small birds. J ournal of Field ornithology, 56 (2): 165-174.

Ridley, M.W. and Islam, K. (1987). Report on Cheer pheasant re-introduction project, Pakistan. In Savage and Ridley (Eds.) Pheasant in Asia 1982. Rekha Printers Pvt. Ltd., New Delhi. 150-166.

Rumble, M.A. and Anderson, S.H. (1993). Evaluating the microscopic fecal technique for estimating hard mast in turkey diets. United States Department of Agriculture Forest Service, 310: 1-4.

Sandfort, W.W. (1954). Evaluation of Chukar partridge in Colorado. C onference Proceeding of the Western Association of State $\mathrm{G}$ ame and F ish C ommi ssions, 34: 244-250.

Satakopan, S. (1972). Keys to the identification of Plant remain in animal droppings. J ournal of Bombay Natural History Society, 60 (1): 139-150.

Sharp, D. (1968). Insects Part I. In Harmer and Shipley (eds.), The Cambridge Natural History. Codicote, England. Wheldon and Wesley, Ltd., Vol. (V): pp.584

Walter, H. and Reese, K.P. (2003). Fall diet of chukars (Alectoris chukar) in eastern oregon and discovery of ingested lead pellets. Western North American N atural ist, 63(3): 402-405.

Warburton, C. (1968). Scorpions, spiders, mites, ticks. In Harmer and Shipley (Eds.), The Cambridge Natural History. Codicote, England. Wheldon and Wesley, Ltd. Vol. (IV).

Westerskov, K. (1966). Winter food and feeding habits of the partridge (Perdix per dix) in the Canadian Prairie. Canadian J ournal of Zoology, 44:303-322. 